\title{
Correction to: Essential oil and aromatic plants as feed additives in non-ruminant nutrition: a review
}

Zhikai Zeng, Sai Zhang, Hongliang Wang and Xiangshu Piao*

Correction to: J Animal Sci Biotechnol 6, 7 (2015) https://doi.org/10.1186/s40104-015-0004-5

Following publication of the original article [1], the authors identified an error in the author name Zhikai Zeng.

The incorrect author name is: Zhaikai Zeng

The correct author name is: Zhikai Zeng

Published online: 11 May 2020

\section{Reference}

1. Zeng Z, Zhang $\mathrm{S}$, Wang $\mathrm{H}$, et al. Essential oil and aromatic plants as feed

additives in non-ruminant nutrition: a review. J Animal Sci Biotechnol. 2015; 6:7 https://doi.org/10.1186/s40104-015-0004-5.

The original article can be found online at https://doi.org/10.1186/s40104015-0004-5.

* Correspondence: piaoxsh@mafic.ac.cn

State Key Laboratory of Animal Nutrition, Ministry of Agriculture Feed

Industry Centre, China Agricultural University, Beijing 100193, China

(c) The Author(s). 2020 Open Access This article is licensed under a Creative Commons Attribution 4.0 International License, which permits use, sharing, adaptation, distribution and reproduction in any medium or format, as long as you give appropriate credit to the original author(s) and the source, provide a link to the Creative Commons licence, and indicate if changes were made. The images or other third party material in this article are included in the article's Creative Commons licence, unless indicated otherwise in a credit line to the material. If material is not included in the article's Creative Commons licence and your intended use is not permitted by statutory regulation or exceeds the permitted use, you will need to obtain permission directly from the copyright holder. To view a copy of this licence, visit http://creativecommons.org/licenses/by/4.0/ The Creative Commons Public Domain Dedication waiver (http://creativecommons.org/publicdomain/zero/1.0/) applies to the data made available in this article, unless otherwise stated in a credit line to the data. 